\title{
DRUŠTVENO-KRITIČKI PRISTUP U GERMANISTIČKOJ NASTAVI KNJIŽEVNOSTI NA PRIMERU ROMANA DOBRI DANI MARKA DINIĆA
}

APSTRAKT: Nadovezujući se na aktuelan književno-didaktički diskurs, ovaj rad za predmet ima analizu dokumenata i kategorizaciju takozvanih književnih kompetencija, kojima bi studenti četvrte godine germanistike trebalo da raspolažu. Istovremeno se u fokus bavljenja književnim tekstovima $\mathrm{u}$ univerzitetskoj nastavi postavljaju njihova literarnost $\mathrm{i}$ društvenopolitička uloga. Pošto didaktiku književnosti posmatramo kao primenjenu nauku i deo socijalnog sistema, pribegli smo kvalitativnoj naučnoj metodologiji i naučnom dizajnu analize dokumenata. Na osnovu kategorizacije i subkategorizacije pojavnih oblika relevantnih za ovo istraživanje, a proizašlih iz sastava ispitanika, došli smo do zaključka da predloženi model odgovara postavljenim ciljevima, te ga kao direktno proizašlog iz nastavne prakse posmatramo i kao skroman doprinos za unapređenje iste.

Ključne reči: literarnost, književnost kao socijalni sistem, društvena kritika, nastava, kvalitativna istraživanja.

\section{SOCIO-CRITICAL APPROACH IN TEACHING GERMAN LITERATURE ON THE EXAMPLE OF THE NOVEL GOOD DAYS BY MARKO DINIĆ}

ABSTRACT: Following up with the current literary didactic discourse, the paper aims at categorizing the so-called literary competences that fourth-year students of German studies should have. At the same time, the focus in dealing with literary texts in university teaching is put on students' literacy and its socio-political role. Since from my point of view the literary didactic is an applied science and also a part of a social system, I used the qualitative scientific methodology and scientific design for document analysis. Based on the categorization and subcategorization of manifestations relevant to this research, and resulting from the students' written assignments, I came to the conclusion that the proposed model corresponds to the goals that were set at the beggining. Therefore, since it comes directly from the teaching practice, I also see it as a modest contribution to their improvement.

Key words: literature, literature as a social system, social critique, teaching, qualitative research. 


\section{AKTUELNA KNJIŽEVNO-DIDAKTIČKA DISKUSIJA}

\subsection{Mesto $i$ uloga književnosti u univerzitetskoj nastavi nemačkog jezika $i$ književnosti}

Književnost u nastavi nemačkog kao stranog jezika može da ima različite pojavne oblike, funkcije, uloge i ciljeve. Sve do sredine 20. veka nastava književnosti u Evropi posmatrana je u sprezi sa idealom humanističkog vaspitanja i obrazovanja - kako u nastavi klasičnih jezika, grčkog i latinskog, tako kasnije nemačkog i kao maternjeg i kao stranog jezika. Nakon uvođenja direktne, audiolingvalne i audio-vizuelne metode sredinom 20. veka, potom i komunikativne metode od sedamdesetih godina prošlog veka, došlo je do radikalne promene didaktičkih ciljeva i činilo se da je književnost „odslužila svoje” (Dobstadt/Riedner 2001: 6). Svakodnevna komunikacija i jezička osposobljenost za svakodnevnu ili pragmatičnu komunikaciju na stranom jeziku bili su osnovni ciljevi nastave. Književni tekstovi - činilo se didaktičarima - nisu imali ni mesta, ni razloga da se opet nađu u nastavi. Tek čuveni pledoaje H. Vajnrajha, kojim upućuje na estetske kvalitete jezika i njihove mogućnosti motivisanja učenika za učenje i komunikaciju, razbijajući uz to „dosadu” učenja jezika (Weinreich 1985: 241) vraća književne tekstove u didaktičku diskusiju u Nemačkoj. Komunikativna didaktika počinje sve više da se interesuje za književne tekstove, što je bilo vidljivo i u uždbenicima i u tematskim časopisima (Dobstadt und Riedner 2001: 6). Alois Virlaher, osnivač interkulturne germanistike i mnogobrojni drugi predstavnici ovog pravca obezbedili su književnim tekstovima stabilno mesto u nastavi stranih jezika početkom osamdesetih godina 20. veka. U osnovnoškolskoj i srednjoškolskoj nastavi oni se uglavnom instrumentalizuju u službi gramatike, lingvokulturologije ${ }^{1}$ ili nekih drugih ciljeva. Krajem 20. i početkom 21. veka interkulturni pristup u nastavi koji polazi od poređenja sopstvene i strane kulture, homogenizujući različite perspektive i dajući pripadnicima strane kulture unapred spremljenje stereotipne etikete, zamenjen je diskursivnim pristupom. Kulturno kontrastivni pristupi (npr. tipično nemačko, tipično srpsko) interkulturne didaktike, te podela u etnički razgraničene kulturne zajednice transformišu se u diskursivne semiotičke koncepte (Altmayer 2009: 123). Predmet interesovanja lingvokulturoloških istraživanja postaju kulturni interpretativni obrasci „kao verovatno objektivne

\footnotetext{
${ }^{1} \mathrm{O}$ interkulturnoj germanistici i lingvokulturologiji opširnije u: Petrović Jilih 2013.
} 
osobine određenih kultura"2 (nem. Als vermeintlich objektive Eigenschaften der jeweiligen Kulturen) (Dobstadt und Riedner 2001: 7). Na primenu raznovrsnih postupaka u radu sa književnim tekstovima, pre svega onih produktivnih, uticali su savremeni pristupi u nauci o književnosti (Zobenica 2018: 17), ali i otkrića iz drugih nauka (lingvistika, nauka o književnosti, radikalni konstruktivizam, kognitivne teorije, psihologija, sociologija, teorija komunikacije), kao i druge vrste umetnosti.

Mišljenja smo da je trenutno najvažnije i goruće pitanje: ŠTA SAD? Svet se nalazi u procesu globalizacije, učenik/student je u centru nastavnog procesa, nastavnik je moderator, kanon je otvoren. Korona i pandemija traju skoro dve godine. Sa pravom postavljamo sledeće pitanje: „Šta da radimo na nastavi nemačke književnosti i kulture na fakultetima?" Naši sadašnji studenti će uskoro postati nastavnici! Nastava književnosti $u$ interkulturnoj germanistici ne treba da instrumentalizuje književne tekstove u druge svrhe, već da njihovoj literarnosti podari centralno mesto. Sticanje književnih kompetencija od strane studenata trebalo bi da bude jedan od najvažnijih ciljeva. Osim toga, studenti treba da razviju svest o kritičkom i samokritičkom pristupu aktuelnim društveno-političkim problemima i pitanjima, da bi i sami vaspitavali i podučavali svoje učenike/studente u samosvesne individue spremne za promene. Ovo su, čini se, glavni ciljevi moderne didaktike književnosti na germanističkim (i drugim filološkim) katedrama u Srbiji.

\subsection{Literarnost u aktuelnoj književno-didaktičkoj diskusiji}

Dobštat i Ridner naglašavaju da se u centar pažnje nastave književnosti mora postaviti upravo naglašavanje posebnosti književne funkcije jezika. Samo tako moguće je postići i ostale ciljeve, kao što su sticanje simboličkih kompetencija i razumevanje stranog jezika. Literarnost ili poetika teksta igra se zvukom, ritmom, formalnim spajanjem, sposobnošću da prebaci pažnju sa smisla na strukturu, čime se ujedno i paradoksalno stvara preduslov za spoznavanje smisla i njegovo novo nastajanje (Dobstadt und Riedner 2001: 10). Ako literarnost nije ekskluzivna specifičnost književnosti, već je oduvek u sastavu jezičkog izraza, onda je književna kompetencija jezička kompetencija koja je bitna i za vanknjiževnu komunikaciju. Razumevanje književnih tekstova je pre svega znanje o tome kako funkcioniše konstrukcija značenja književnih tekstova (Dobstadt und Riedner

\footnotetext{
${ }^{2}$ Sve prevode u tekstu sačinila je autorka.
} 
2014: 162-163). Najdlinger i Pazevalk, takođe, polaze od postavke da poetski jezički oblik nije specifičnost samo književnog jezika, već jezika uopšte. Oni u centar svojih razmatranja stavljaju „potencijal književnog jezika i forme” (nem. Potenzial von literarischer Sprache und Form) (Neidlinger und Pasewalck 2014: 142), pledirajući međutim za veću kompleksnost nastave jezika, čime opet instrumentalizuju književni tekst i njegovu literarnost. Književno otuđenje (nem. Verfremdung) je odlika književnog teksta koju razmatra Šidermajer. Pri tome upućuje nas i na vezu književnih tekstova sa društvenim procesima i kulturnim diskursima (Schiedermair 2014: 132). Oni koji uče strani jezik bi trebalo da vladaju i „simboličkom kompetencijom”. Ta kompetencija se posebno stiče čitanjem književnih tekstova. Sposobnost za opažanje stranosti, razlika, otuđenja, mnogoznačnosti i ambivalencije samo su neke njene komponente. Kao sastavni deo komunikativne nastave, studentima treba ponuditi suočavanje sa poetskim, osećajnim i ideološkim dimenzijama tekstova, kao i njihovo tumačenje. (Kramsch 2001: 36). Leskovec smatra da je funkcija književnih tekstova u internacionalnoj germanistici $^{3}$ sa jedne strane književno-naučna, a sa druge društveno-politička. Kada je deo kulturološke nauke o književnosti, književnost se u prvoj liniji proučava sa aspekata kulturne komunikacije i delanja i u istraživanjima se služi kulturološkim metodama. Ali, interkulturna nauka o književnosti pokušava da se, pre svega, bavi specifičnom strukturom književnih tekstova, što je moguće isključivo korišćenjem književno-naučnih metoda. $U$ ovom smislu se germanistička književnost bavi tekstinternim i teksteksternim, tj. kontekstualnim postupcima. Kod ovih prvih posebno su relevantne receptivna estetika, hermeneutika, strukturalizam, naratologija i dekonstruktivizam. Ovakva nauka o književnosti treba da bude predmet na fakultetima internacionalne germanistike (Leskovec 2014: 120). U ovom smislu se Šlibar zalaže za univerzitetsku (ali i školsku) nastavu književnosti kao nastavu čiji je osnovni cilj da studenti književne tekstove čitaju rado i sa zadovoljstvom (Šlibar 2011: 14). Ovo je moguće samo ako prihvate njihovu sedmostruku stranost ${ }^{4}$ i razviju odgovarajuće književne kompetencije (Šlibar 2014: 41-50). Neophodni koraci za rešavanje problema u sistemu u kome želja i nelagoda fungiraju kao metoda, sistem i struktura su

\footnotetext{
${ }^{3}$ Pod internacionalnom germanistikom podrazumevamo germanističke studije na nematičnim fakultetima, što nikako ne treba mešati sa interkulturnom germanistikom.

4 Sedmostruku stranost književnih tekstova po Nevi Šlibar čine: sistemska, funkciona, strukturna, interkulturna, receptivna, diskursivna i situativna stranost (Šlibar 2014: 41-50, Petrović Jilih 2016: 39-43).
} 
samoposmatranje, samorefleksija, verbalizacija želje, volje i nelagode i identifikacija stranosti (u nama samima) (Šlibar 2014: 50).

\subsection{Književno-didaktički model $i$ osposobljavanje za udubljivanje u svetove književnih tekstova}

U književno-didaktičkom modelu koji predlažemo za univerzitetsku nastavu germanistike važna uloga data je interaktivnoj nastavi i komunikativnim zadacima ${ }^{5}$. Raznovrsne nastavne metode treba da motivišu studente na rad i da ih osposobe da čitaju skrivene kodove u tekstovima. To znači da se analitičkim, interpretativnim, produktivnim postupcima produbljuju i stiču književnoistorijska, književnoteorijska, kulturološka, analitička i mnoga druga znanja i kompetencije potrebne za uspešno „otključavanje” tekstualnih kodova.

$\mathrm{U}$ tom modelu:

- književnost se shvata kao socijalni sistem koji je institucionalizovan i relevantan za celo društvo;

- ophođenje sa književnim tekstovima podrazumeva kako njihovu recepciju i obradu tako i produkciju i distribuciju;

- kulturni interpretativni obrasci implicirani u književnim tekstovima treba da budu predmet svesnog tumačenja, a studenti treba svesno da se suoče sa pojmom kulture, koji ne počiva na etničkim, već jezičkim zajednicama;

- regulativa značenja postavlja se u individualne i socijalne kontekste;

- u središtu socijalnog sistema književnosti su njegovi akteri koji se na različite načine na kognitivnoj, normativnoj i emotivnoj ravni suočavaju sa poetskom funkcijom književnih tekstova.

Da bi se suvereno i sa željom kretali po „slobodnom prostoru književnosti” (nem. Freiraum Literatur) studenti moraju da poznaju ovaj prostor i da se po njemu kreću kao po čudesnom svetu lavirinata sa njihovim ponavljanjima, protivurečnostima i prerušavanjima (Šlibar 2011: 14).

Cilj posredovanja književnosti unutar univerzitetskog okvira je, dakle, aktivna i potencijalno svesna recepcija i obrada književnosti. Pri tome se ne radi o o prenošenju ,ispravnog značenja teksta”, već se, pored subjektivno zadovoljavajućeg i koherentnog dodeljivanja komunikata na ravni kognicije, radi i o sposobnosti da se udovolji očekivanjima drugih partnera u komunikaciji na

\footnotetext{
${ }^{5}$ Opširnije o modelu u Petrović Jilih 2016: 50-55.
} 
socijalnoj ravni. To u okviru germanističkog učenja znači da treba poznavati i načine čitanja koji su priznati od strane nauke o književnosti i književne kritike (Müller-Peisert 2005: 146). ${ }^{6}$

\section{METODOLOGIJA ISTRAŽIVANJA}

\subsection{Ciljevi, istraživačka pitanja, analitički aparat}

Kako u novonastalim uslovima onlajn nastave nedostaje bitan stub teorijskog didaktičkog konstrukta - komunikacija i regulacija o komunikatima, tj. konstruisanim značenjima u okviru nastavne zajednice, te nemogućnost primene velikog broja metoda i učešća u nekim ulogama književnosti kao socijalnog sistema, trebalo je nanovo osmisliti nastavu iz predmeta. Prihvatajući moto Neve Šlibar „Književnost za čitav život” (nem. Literatur für das Leben) (Šlibar 2014: 13), postavljena istraživačka pitanja glase: Da li je predstavljen model efikasan za postizanje glavnog cilja? Da li su studenti četvrte godine germanistike osposobljeni za samostalno udubljivanje (zaronjavanje) i užitak u književnim tekstovima? U glavne ciljeve nastave spadaju ostvarivanje funkcija književnosti kao socijalnog sistema na emotivnom, moralnom i kognitivnom nivou (uporedi Petrović Jilih). Neophodno je, između ostalog, ostvarivanje dole navedenih ciljeva, koji će ujedno biti i analitičke kategorije. Ciljevi su preuzeti od Šlibar i Leskovec i prilagođeni su potrebama istraživanja:

- samoposmatranje i samorefleksija;

- verbalizacija emocija, oduševljenja i nelagode prilikom čitanja i obrade književnih tekstova;

- identifikacija raznih vrsta stranosti (teksta, konstrukcije sveta, nas samih);

- razvoj kritičkog i produktivnog mišljenja (Šlibar 2011: 50);

- reakcija na društvene procese (razvoj lične i grupne odgovornosti i volje za promenama) (Leskovec 2014: 121).

\footnotetext{
${ }^{6}$ Nem. Ziel der Literaturvermittlung im universitären Rahmen ist also die aktive und potentiell bewußte Rezeption und Verarbeitung von Literatur. Dabei geht es nicht um die Ermittlung von ,richtiger Textbedeutung“, sondern neben der subjektiv befriedigenden und kohärenten Kommunikatzuordnung auf der Ebene der Kognition um die Fertigkeit, auf der sozialen Ebene den Erwartungen anderer Kommunikationspartner zu entsprechen. Das heißt im Rahmen der germanistischen Lehre auch, Lesarten zu kennen, die von der Literaturwissenschaft und Literaturkritik anerkannt sind.
} 


\subsection{Kriterijum za izbor tekstova}

Izbor glavnog teksta Als wir träumten (Dok smo sanjali) Klemensa Majera (Clemens Meyer), objavljenog 2006. godine, i sporednih tekstova - romana Die guten Tage (Dobri dani) Marka Dinića iz 2019. godine, te filmova Zbogom, Lenjne! (Goodbye Lenin) (2003) i Životi drugih (Das Leben der Anderen) (2006) ispunjavaju sve kriterijume koje je predložila Neva Šlibar (Šlibar 2011: 92-98), sa posebnim osvrtom na ciljeve postavljene u ovom konkretnom nastavnom projektu. Odabrani tekstovi su:

- prilagođeni postavljenim ciljevima nastave;

- sagledani i recipirani kao celina;

- odgovaraju jezičkim kompetencijama studenata;

- aktuelni su u smislu mogućnosti uspostavljanja veze između sveta tekstova i sveta u kome recipijenti žive;

- nude brojne kulturne interpretativne obrasce nemačke govorne zajednice;

- imaju visoku književno-umetničku vrednost;

- imaju potencijal da emotivno i intelektualno zainteresuju studente kao što su emotivno i intelektualno zainteresovali nastavnicu (opširnije u: Petrović Jilih 2016: 71-75).

\subsection{Primer iz prakse ${ }^{7}$}

Budući da lingvokulturologija na Katedri za germanistiku na Filološkoumetničkom fakultetu Univerziteta u Kragujevcu nije zastupljena kao samostalan predmet, već samo sa dva slična predmeta: Nemačke teorije kulture kao izborni predmet u zimskom semestru na četvrtoj godini studija i Kulturno-politička istorija Nemačke 20. veka na master studijama, odlučili smo da je ugradimo u nastavu na predmetima na četvrtoj godini studija germanistike u letnjem semestru 2021. godine: Produktivan rad sa književnim tekstovima i Nemačka književnost 20. veka $2^{8}$.

Odlučili smo se za integraciju oba predmeta. Pretpostavka je bila da su studenti i studentkinje u prethodne tri godine studija stekli dovoljno književnih kompetencija neophodnih za razumevanje književnih tekstova. Posedovanje

\footnotetext{
7 Isti primer iz nastavne prakse, ali sa različitim istraživačkim pitanjima i ciljevima, korišćen je za još dva istraživanja, čiji će rezultati tek biti objavljeni. Zato u radovima može doći do preklapanja pri predstavljanju plana nastave.

${ }^{8} \mathrm{Na}$ ovom predmetu radi se i sa tekstovima iz 21 . veka.
} 
književnoteorijskih i književnoistorijskih znanja neophodno je za ulazak u fikcionalni višeznačni socijalni sistem književnost (kognitivna funkcija književnosti). Potpuno razumevanje tekstova omogućava studentima uživanje u njima (emocionalna funkcija), te normativno sporazumevanje (moralna funkcija) kao što su građenja identiteta, razbijanja tabua i predrasuda, argumentovano predstavljanje sopstvenog mišljenja, prevazilaženja konflikata (o funkcijama opširnije u Petrović-Jilih (2016: 30-31) i Šmit (1991: 111).

Sledeći korak bio je izbor odgovarajućih metoda, odnosno načina rada, aktivnosti nastavnika i učenika koji će dovesti do ostvarenja željenog cilja. Svaka odabrana metoda treba da bude u službi cilja i prilagođena učenicima, pri čemu prednost treba davati onim metodama koje doprinose razvoju ličnosti učenika i njihovih sposobnosti, odnosno metode kod koje u središtu pažnje nije nastavnik (Zobenica 2018: 230).

"Metodski repertoar interkulturnih treninga” (Honeff-Becker 2006: 16) preuzet je od Honef-Beker, prerađen i korišćen za potrebe naše nastave na sledeći način:

1. receptivni postupci - čitanje/gledanje/slušanje tekstova, detaljno ponovljeno čitanje;

2. refleksija i samorefleksija - pisanje biografije;

3. produktivni postupci - razne vrste kreativnog i produktivnog pisanja (scenski prikazi, pozorišno-pedagoški performansi - obavezni u uslovima „normalne” nastave ovde nisu mogli biti primenjivani);

4. analitički postupci - analiza filmskih i književnih tekstova.

Nakon didaktičkih razmišljanja, u nastavne jedinice (dva puta po 90 minuta) raspodeljeni su zadaci i formiran je koncept nastave zasnovan na produktivnom pisanju:

1. Napiši sastav, pesmu, esej ili biografiju pod naslovom Moje detinjstvo $i$ mladost u Srbiji (Meine Kindheit und Jugend in Serbien);

2. Pročitaj roman Marka Dinića Dobri dani (Die guten Tage);

3. a) Napiši komentar sa osvrtom na tekst (potkrepi argumente citatima iz teksta, iz novina, časopisa, sa interneta) na temu:

Pisci lažu! (Die Dichter lügen!) ili

Ma to nije istina (Das ist doch nicht wahr) ili

To nije zemlja u kojoj živim i koju volim. A možda i jeste? (Das ist nicht das Land in dem ich lebe und das ich liebe. Oder doch?)

b) Istočna Nemačka i ujedinjenje (toliko znam o tome) (Das weiß ich über 
die DDR und die Wende).

4. Pogledaj film Good Bye, Lenin!

5. Pogledaj film Das Leben der Anderen.

6. Napiši filmsku kritiku o izabranom filmu sa posebnim osvrtom na kulturne interpretativne obrasce.

7. Književno-naučna analiza uvodnog dela romana Als wir träumten Klemensa Majera.

8-11. Individualno čitanje teksta.

12. čas: Napiši sastav na temu Moje/tvoje/njegovo/naše/njihovo detinjstvo $i$ mladost u NDR-u i nakon ujedinjenja (Meine/deine/seine/ihre Kindheit und Jugend in der DDR und nach der Wende).

13, 14. i 15. čas: Evaluacija nastave (razgovor, diskusija, individualni intervjui).

\section{EMPIRIJSKO ISTRAŽIVANJE, ANALIZA I REZULTATI ISTRAŽIVANJA}

\subsection{Polje istraživanja}

Polje istraživanja obuhvata studente i studentkinje četvrte godine germanistike na Katedri za nemački jezik i književnost Filološko-umetničkog fakulteta u Kragujevcu. Iako dolaze iz različitih krajeva Srbije, čine relativno homogenu grupu sa istim ili sličnim obavezama na fakultetu i sličnim izgledima za zapošljavanje kao nastavnici, prevodioci, kulturni menadžeri, saradnici u kulturnim i društvenim institucijama i slično. Dobijeni rezultati o vladanju ključnim kompetencijama, književnim kompetencijama i književnim kompetencijama u kontekstu sposobnosti reflektovane društvene kritike imaju uopštenu dimenziju. U osmom semestru onlajn nastave akademske 2020/2021. godine u nastavi na obaveznim predmetima Nemačka književnost 20. veka 2 i Produktivan rad sa književnim tekstovima učestvovalo je dvadeset studenata. Od njih dvadeset, sastav o romanu Dobri dani pisalo je njih sedamnaest.

\subsection{Analiza dokumenata ${ }^{9}$}

Istraživanje je vršeno postupkom koji spada u klasično polje kvalitativnointerpretativne analize (Mayring 2002: 46) pri obradi jezičkog i nejezičkog

\footnotetext{
${ }^{9}$ Sastavi su pisani na nemačkom jeziku. Kako bi ovo istraživanje bilo dostupno i svim zainteresovanima koji ne vladaju znanjem nemačkog jezika, odlučili smo da sve navedene iskaze prevedemo na srpski jezik.
} 
materijala: opisnom analizom dokumenata. U dokumente ne spadaju samo diplome, potvrde i pisani izvori od posebnog značaja, ,dokument može da bude sve, tekstovi, filmovi, tonski zapisi, ali i predmeti kao što su alati, građevine, umetnički predmeti” (Mayring 2002: 47) ${ }^{\mathbf{1 0}}$.

Važno je da nas odabrani dokumenti dovode do važnih zaključaka o ljudskim mišljenjima, osećanjima i delanjima, tj. da se mogu interpretirati (Ibid.: 47). Prva prednost ovog istraživačkog dizajna je raznovrsnost materijala. Druga prednost je u tome što je materijal već spreman $\mathrm{i}$ istraživači ne moraju da ga prave $\mathrm{i}$ testiraju. Subjektivnost istraživača je time svedena na izbor dokumenata. Analizi dokumenata može se pribeći kad god postoje valjani izvori dokumenata za rešavanje istraživačkih zadataka. Kvalitatitvna interpretacija materijala igra odlučujuću ulogu u postupku koji se sastoji iz sledećih koraka:

1. postavka analitičkog aparata i istraživačkih pitanja;

2. navođenje dokumenata koji se analiziraju;

3. kritika izvora i sagledavanje iskazne vrednosti dokumenata za istraživačka pitanja;

4. interpretacija dokumenata (Mayring 2002: 48-49).

\subsection{Pojedinačni slučaj Tea}

U našem istraživanju analiziraćemo samo jedan reprezentativni dokument, dok ćemo na osnovu ostalih koji su pisani kao produktivan odgovor na književni tekst Dobri dani Marka Dinića predstaviti nastale kategorije relevantne za istraživanje. Polazimo od činjenice da studenti poseduju veliki broj književnih kompetencija koje im omogućavaju razumevanje književnih tekstova, te one neće biti posebno analizirane. Više pažnje biće posvećeno ostvarivanju tri funkcije socijalnog sistema književnosti: emotivne, normativne i kognitivne, kao i samokritičkoj i kritičkoj osposobljenosti da reaguju na društvenu kritiku izraženu u tekstu.

Verbalizujući utiske i emocije koje je ovaj tekst na njih ostavio, studentkinje $^{11}$ pokazuju visok stepen sposobnosti (samo)posmatranja, (samo)refleksije i (samo)kritike, koje će biti prikazane u kratkoj analizi slučaja Tea.

Posle par stranica knjige Dobri dani Marka Dinića meni se smučilo. Nisam mogla da verujem šta sam ja to pročitala i htela sam da prekinem čitanje. Prvo osećanje

10 ... kann Dokument alles sein, Texte, Filme, Tonbänder, aber auch Gegenstände wie Werkzeuge, Bauten, Kunstgegenstände.

${ }^{11} \mathrm{U}$ istraživanju su učestvovale studentkinje. 
koje je nekontrolisano raslo u meni je bio bes. Iako ne mogu o sebi da kažem da sam baš neki veliki patriota, bila sam razočarana i povređena. Povređena zbog reči jednog nepoznatog čoveka o mojoj zemlji, zemlji u kojoj sam rođena, u kojoj živim i koju volim.

Emocije koje su se prilikom prvog čitanja književnog teksta javile kod studentkinje jesu pre svega nekontrolisani nalet besa, neverica, razočaranje, uzburkanost osećanja i implicitno prisutnog ,nacionalnog” ponosa. Iako za sebe smatra da ,nije neki veliki patriota” priznaje da voli zemlju u kojoj je rođena, te ne može da toleriše ružne reči o njoj koje izgovara „neki nepoznati čovek”. Zato je htela da sazna identitet tog čoveka - pisca ovog teksta, te se nekoliko puta vraćala na omot knjige, ne verujući sopstvenim očima da se njegovo ime završava na -ić. Ovo iznenađenje komentariše jednom jedinom rečju: „Grozno!”

Vratila sam se par puta na naslovnu stranu knjige i pročitala njegovo ime. Nisam mogla da verujem kako neko, čije se prezime završava na -ić, može da napiše tako nešto. Grozno.

Na ovom mestu je moglo da dođe do prekida čitanja zbog neprihvatanja slike sveta predstavljene u književnom tekstu. Iz besa, ali verovatno i radoznalosti, Tea je na Guglu (Google) pokušala da pronađe biografiju autora. Time ukazuje na svoj pokušaj da, istražujući kontekst teksta, pokušava $i$ da ga shvati. To nam ukazuje na činjenicu da je studentkinja identifikovala stranost pisca, teksta i sebe same i bila spremna na pokušaj ,trpljenja” drugačijeg:

Rođen u Beču, odrastao u Beogradu i onda se vratio u Beč. Sedi malo, ako ti sve ovo što čitaš toliko smeta, rekla sam sama sebi. Ali udubljujući se u knjigu i odaljavajući se od prvih utisaka postajalo mi je sve jasnije da je autor ipak možda u pravu i da je sve ovo što piše prava slika našeg naroda, mog naroda. Sa pročitanim stranicama sve više sam se slagala sa rečima koje sam čitala.

Tea nije prekinula čitanje lektire, već joj je, što se više udaljavala od prvog utiska bivalo sve jasnije da treba da promisli o tome da li autor zaista greši ili je ipak u pravu. Prihvatajući perspektivu autora, odnosno pripovedača, ona zaključuje da u knjizi pronalazi ,pravu sliku našeg naroda, mog naroda”. Narod za Teu predstavlja etničku zajednicu koju generalizuje, uopštava i kojoj samim tim daje stereotipne odlike. Glavni lik je fascinira. Vrativši se nakon puno godina $u$ zemlju koju mrzi iz bega na Zapad, bega od realnosti, od oca, autoriteta, poslušnosti, bega od srpskog nacionalizma, on je zapravo simbol jedne generacije u koju se ispitanica empatijski uklapa.

Kritika našeg društva koju sam ovde pročitala istovremeno me je i iritirala i slagala sam se sa njom. „Und ich bin der festen Überzeugung, dass Angst, Feigheit und Schuld einander bedingen, über alle Generationen hinweg. Leiden die Leute in 
Serbien nicht gerade daran am meisten?" (s. 100) Da, to je tačno. Bes koji se provlači kroz knjigu je nešto sa čim mnogi ljudi ove generacije mogu da se identifikuju i od kojih su mnogi pre davnog vremena napustili Srbiju.

Kritičko razmišljanje dovelo je do toga da Tea saoseća sa pripovedačem i deli njegovo (loše) mišljenje o mnogim društvenim prilikama u zemlji. Ona, čak, razmišlja o kolektivnoj krivici, koju imenuje kao ,kolektivna osećanja koja smo indirektno preživeli". Slika grada Beograda za nju predstavlja i druge gradove u zemlji: propadanje, smrad, pustošenje - teške su reči - kaže ona, ali su i prikladne. Tea reaguje na društvene procese i imenuje društvene tabue. Verbalizuje najdublja osećanja, pokušava da pronađe rešenja uspostavljanjem transfera između sveta teksta i sveta koji je okružuje. Spremna je za promene i identifikaciju različitih vrsta stranosti. Imenuje probleme, ne ustežući se da društvo u kome živi nazove distopijom:

Ne volim što smo postali ovo što smo postali, niti volim put kojim idemo. Možda distopija i nije samo reč, možda je to realnost. Naša realnost.

\subsection{Relevantne kategorije kompetencija}

$\mathrm{Na}$ osnovu ostalih izjava mogu se idvojiti sledeće kategorije koje su relevantne za ovaj rad i koje ćemo bez detaljne analize dokumentovati odabranim citatima:

- $\quad$ samoposmatranje i samorefleksija:

Sve me je podsetilo na to koliko je uvrnuta, nepregledna i distopijska cela situacija u ovoj zemlji. (Minja)

- verbalizacija emocija, oduševljenja i nelagode prilikom čitanja i obrade književnih tekstova:

Ja sam bila veoma iznervirana. Ali ta iznerviranost je varirala. Od one iznerviranosti koja je budila ljutnju, onu najgoru moguću, ljutnju na svet, na pripovedača koji od nas stvara agresivne, jednom rečju glupe i prazne ljude, koji sebe žale, do iznerviranosti kao bespomoćnosti, koja potvrđuje istinu, istinu koja boli i koja nas pomno prati koliko god mi bežali od nje i bezuspešno je skrivali, koja potvrđuje strahove prožete porodičnim odnosima, uticajem politike. (Lola)

- identifikacija raznih vrsta stranosti (teksta, konstrukcije sveta, nas samih):

Svako poznaje makar jednu osobu iz okruženja ili iz porodice, koja živi već dugo $\mathrm{u}$ inostranstvu, ili to planira da uradi. Mnogi od njih veoma retko posećuju svoju zemlju, neki od njih čak i izgube identitet kao Srbi i osećaju se kao stranci kada se vrate. Oni su, baš kao i naš junak, rascepljeni na hiljadu delova i pokušavaju da se sastave, budeći sećanja na određena mesta, na događaje i ljude. (Mona) 
- razvoj kritičkog i produktivnog mišljenja:

Ova knjiga me podseća na moj svakodnevni, unutrašnji, nesvestan pokušaj da shvatim šta se sve to trenutno događa, a što se očigledno tiče prošlosti ove zemlje. Čega se sećamo, a šta znamo sa sigurnošću dve su potpuno različite stvari. (Minja)

- reakcija na društvene, političke i istorijske procese (razvoj lične i grupne odgovornosti i volje za promenama):

Dakle, ja želim da ostanem ovde da bih pokušala što više da naučim o stvarima koje se moraju promeniti, ali i o onima koje treba sačuvati. Optimista sam jer mi se čini da su mladi ljudi iz mog okruženja poprilično spremni da se bore za promene, da prihvate različitosti. Želim da verujem da se strah od nepoznatog i stranog polako smanjuje i pretvara u radoznalost. A radoznalost je prvi korak koji vodi ka promeni. (Lina)

\subsection{Rezultati analize i kategorizacije}

Rezultati pokazaju da studentkinje vladaju književnim kompetencijama po opštem modelu kompetencija za nastavu književnosti (model Ulfa Abrahama po Šlibar 2011: 56):

1. stručno-jezička kompetencija - studentkinje uspešno primenjuju književno-naučne pojmove;

2. poetska kompetencija - poseduju sposobnost građenja imaginarnih svetova i stvaranja istorijske svesti;

3. interaktivna kompetencija - poseduju sposobnost izražavanja sopstvenog razumevanja književnog teksta $u$ odnosu na druge načine razumevanja i čitanja;

4. moralna kompetencija - poseduju sposobnost etičkog vrednovanja fikcionalnog teksta;

5. kognitivna kompetencija - stiču književna, socijalna, ekonomska i politička znanja;

6. rezultati istraživanja pokazuju da studentkinje samouvereno učestvuju u socijalnom sistemu književnosti. Služe se stručnom terminologijom, reaguju na predstavljene modele svetova i karaktera, verbalizuju skrivene i potisnute emocije, kritikuju društvo i argumentuju sva svoja mišljenja, navodeći citate iz teksta ili primere iz sopstvenog života. Osuđujući događaje iz prošlosti, jasno su usmerene ka humanističkim i demokratskim idejama, poštovanju drugačijeg, odbacivanju govora mržnje, nacionalizma, nasilja, te želji da „menjaju svet”. 


\section{ZAKLJUČAK}

Iz istraživačkih pitanja i postavljenih ciljeva proistekle su i potvrđene sledeće hipoteze:

- Studenti i studentkinje germanistike u osmom semestru poseduju književno-naučno znanje koje im omogućava da se samostalno uhvate u koštac sa kompleksnim književnim tekstovima, prepoznajući njegove eksterne i interne kontekste. Studentkinje poseduju strategije „književnonaučnog čitanja" (Leskovec 2014: 122)

- Studentkinje su pokazale spremnost za preuzimanje kako lične tako i kolektivne odgovornosti za društveno-političke prilike u kojima žive.

- Studentkinje su čitanjem, razumevanjem, obradom teksta učestvovale u socijalnom sistemu književnosti na sve tri njegove ravni: emocionalnoj, moralnoj i kognitivnoj.

- Osposobljene su da sa oduševljenjem uđu u fiktivne svetove, na njih reaguju i kritički ih analiziraju i tumače.

- Konstruktivnom tumačenju prišle su na kreativan i produktivan način.

Ovaj rad je pledoaje za germanističku nauku o književnosti sa fokusom na literarnosti, društveno-političkom aktiviranju i interkulturalnosti. Fokus bi mogao i trebalo bi ga preneti i na druge katedre germanistike u Srbiji. Predloženi didaktički model bi trebalo modifikovati čim se za to steknu uslovi, odnosno čim se pređe na neposrednu nastavu. Mnogobrojna pitanja koja se ovde otvaraju ukazuju na potrebu za daljim istraživanjima u oblasti empirijske didaktike književnosti. U vezi sa ovim, značajno bi bilo ispitati kojim književnim i socio-kulturnim kompetencijama vladaju studenti i studentkinje na mlađim godinama studija (uključiti i fakultete iz drugih gradova), kako modernizovati i u kom pravcu menjati silabuse iz ovih predmeta na osnovnim i master studijama, na koji način se izvodi nastava književnosti i kulture na germanističkim katedrama u zemlji, te šta nastavnici misle o sadašnjem stanju u nastavi i njegovim promenama. Od velike važnosti bi bilo i sprovođenje pojedinačnih intervjua i grupnih diskusija.

Glavni cilj nastave preuzeli smo od Neve Šlibar: „Književnost za čitav život!" Samo ostvarivanje funkcija književnosti kao komunikativnog sistema na sva tri nivoa - emotivnom, normativnom i kognitivnom može studente i studentkinje da preobrazi u buduće dobre nastavnike i nastavnice, koji će sa istim oduševljenjem prenositi zarazu i ,pedagoški eros” u ophođenju sa književnim 
tekstovima na svoje đake. „Energija nam je potrebna ne samo da bismo izašli na kraj sa školskom svakodnevnicom, već upravo sa nastavom književnosti, jer ništa nije zaraznije od sposobnosti za oduševljavanjem: i onda kada se učenici i učenice prave „cool” i nezainteresovani, sigurno ćete moći Vašim entuzijazmom da ih povučete za sobom. Energija koja dolazi iz „,pedagoškog erosa” istovremeno je neiscrpna; zarazom se proširuje i obnavlja" (Šlibar 2014: 9) ${ }^{12}$.

\section{LITERATURA}

Dinić, M. (2019). Die guten Tage. Wien: Paul Zolnay.

Mayer, C. (2010). Als wir träumten. Frankfurt am Main: Fischer (erste Auflage 2006).

Altmayer, C. (2009). Instrumente für die empirische Erforschung kultureller Lernprozesse im Kontext von Deutsch als Fremdsprache, in Interkulturelle Kompetenz und fremdsprachliches Lernen. Modelle, Empirie, Evaluation, Hrsg. A. Hu, M. Byram (Tübingen: Narr): 123-138.

Altmayer, C. (2004). Kultur als Hypertext. München: Iudicium.

Altmayer, C. (2014). Zur Rolle der Literatur im Rahmen der Kulturstudien Deutsch als Fremdsprache, in Literatur in Deutsch als Fremdsprache und internationaler Germanistik. Konzepte, Themen, Forschungsperspektiven, Hrsg. C. Altmayer u.a. (Tübingen: Stauffenburg Verlag): 25-37.

Dobstadt, M./Riedner, R. (2014). Zur Rolle und Funktion der Literatur und des Literarischen in Deutsch als Fremd- und Zweitsprache. Forschungsfeld und Forschungsperspektiven der Literaturwissenschaft im Fach, in Literatur in Deutsch als Fremdsprache und internationaler Germanistik. Konzepte, Themen, Forschungsperspektiven, Hrsg. C. Altmayer u.a. (Tübingen: Stauffenburg Verlag): 119-130.

Kramsch, C. (2001). Symbolische Kompetenz durch literarische Texte, in Fremdsprache Deutsch 44 (Ismanning: Hueber Verlag): 53-59.

Leskovec, A. (2014). Literaturwissenschaftliche Methoden im fremdsprachlichen Literaturunterricht, in Literatur in Deutsch als Fremdsprache und

\footnotetext{
${ }^{12}$ Nem. Energie benötigt man/frau nicht nur, um den Schulalltag zu meistern, sondern gerade beim Literaturunterricht, denn nichts ist ansteckender als Begeisterungsfähigkeit: Auch wenn die SchülerInnen ,cool“ tun und desinteressiert, werden Sie sie durch Ihren Enthusiasmus mit sich reißen können. Die Energie, die aus dem pädagogischen Eros kommt ist gleichsam unerschöpfbar; durch Ansteckung erneuert sie sich.
} 
internationaler Germanistik. Konzepte, Themen, Forschungsperspektiven, Hrsg. C. Altmayer u.a. (Tübingen: Stauffenburg Verlag): 141-152.

Müller-Peisert, G. (2005). Zum Verstehen fremdkultureller Literatur. Ein Vergleich der Konventionen im Umgang mit literarischen Texten am Beispiel Deutschland und China. Kassel: Universität Kassel.

Neidlinger, D./Pasewalck, S. (2014). Das Potenzial literarischer Sprache und Form im Bereich Deutsch als Fremdsprache. Ein Plädoyer für Kompläxität im Fremdsprachenunterricht, in Literatur in Deutsch als Fremdsprache und internationaler Germanistik. Konzepte, Themen, Forschungsperspektiven, Hrsg. C. Altmayer u.a. (Tübingen: Stauffenburg Verlag): 141-152.

Petrović Jilih, M. (2013). Didaktika, lingvokulturologija i književnost u interkulturnoj germanistici, u Sprache und Literatur diesseits und jenseits der Mauer(n)=Jezik i književnost s obe strane zida: Festschrift für Božinka Petronijević zum 65. Geburtstag = zbornik u čast Božinke Petronijević povodom 65. rođendana, ur. D. Nedeljković, N. Vujčić (Kragujevac: FILUM): 331-344.

Petrović Jilih, M. (2016). Svi smo bili tekst... Kragujevac: FILUM.

Šlibar, N. (2011). Wie didaktisiere ich literarische Texte?: neue Maturatexte und viele andere im DaF-Unterricht. Ljubljana: Znanstvena založba Filozofske fakultete.

Schiedermair, S. (2014). Deutsch als (ver)fremde(te) Sprache. Literarische Verfremdung als Kategorie im Fach Deutsch als Fremdsprache, in Literatur in Deutsch als Fremdsprache und internationaler Germanistik. Konzepte, Themen, Forschungsperspektiven (Tübingen: Stauffenburg Verlag): 131140.

Schmidt, S. J. (1991). Grundriß der Empirischen Literaturwissenschaft. Frankfurt am Main: Suhrkamp.

Weinreich, H. (1985). Von der Langeweile des Sprachunterrichts. Wege der Sprachkultur. Stuttgart: Deutsche Verlagsanstalt.

Zobenica, N. (2018). Didaktika nemačke književnosti kao strane. Novi Sad: Filozofski fakultet. 
Marina M. Petrović Jilih

University of Kragujevac

Faculty of Philology and Arts

\section{SOCIO-CRITICAL APPROACH IN TEACHING GERMAN LITERATURE ON THE EXAMPLE OF THE NOVEL GOOD DAYS BY MARKO DINIĆ}

\section{Summary}

Following up with the current literary didactic discourse, the paper aims at analyzing and categorizing the so-called literary competences that fourth-year students of German studies should have. At the same time, the focus in dealing with literary texts in university teaching is put on students' literacy and its socio-political role. Since from my point of view the literary didactic is an applied science and also a part of a social system, I used the qualitative scientific methodology and scientific design of document analysis. Starting from research questions, whether and to what extent students are trained to use literary texts in their work as future teachers and whether and to what extent they are able to transfer to their students the key educational competencies of democratic social values with the principle of mediation, but also whether the suggested didactic model in the conditions of online teaching managed to meet the needs of teaching, the following goals have been set: preparing the students for independent, argumentative, critical and self-critical reading and interpretation of texts and cultural patterns in them. Based on the categorization and subcategorization of manifestations relevant to this research and resulting from the analysis of the students' written assignments, I came to the conclusion that the proposed model corresponds to the goals that were set at the beggining. Therefore, since it comes directly from the teaching practice, I also see it as a modest contribution to their improvement.

Key words: literature, literature as a social system, social critique, teaching, qualitative research.

Primljeno: 30. 4. 2021.

Prihvaćeno: 20 7. 2021. 
